\title{
Evaluation of an organic package of practice towards integrated management of Solanum tuberosum and its comparison with conventional farming in terms of yield, quality, energy efficiency and economics
}

\author{
Antara SEAL ${ }^{1 *}$, Ranjan BERA ${ }^{1}$, Anupam DATTA ${ }^{1}$, Susmita SAHA ${ }^{1}$, Rupkatha ROY CHOWDHURY ${ }^{1}$, Kajal \\ SENGUPTA $^{2}$, Arun Kumar BARIK ${ }^{3}$, Ashis Kumar CHATTERJEE ${ }^{4}$
}

Received January 30, 2017; accepted August 23, 2017.

Delo je prispelo 30. januarja 2017, sprejeto 23. avgusta 2017.

\begin{abstract}
A study was taken up during 2014-16 for evaluating the potential of an organic package of practice towards integrated crop production (green farming) in comparison to conventional farmers' practice in West Bengal, India. Under green farming, compost was integrated with chemical fertilizer for soil management while organic plant/ pest management was undertaken utilizing Inhana Rational Farming (IRF) Technology. The study indicated higher yield (9.7\%), higher nutrient use efficiency and economic sustainability under green farming irrespective of study area or potato variety. Higher qualitative expression in terms of starch content, pulp $\mathrm{pH}$, vitamin $\mathrm{C}$ etc. under green farming might be due to the organic plant management aimed at energization of plant biochemical functions. Soil quality development as noted under green farming might have been influenced by the onfarm produced compost containing rich self- generated micro flora (in order of $10^{16}$ per colony forming unit.). The study indicated that green farming may serve as an efficient substitute of conventional farming towards yield sustenance, abatement of food toxicity and quality end product; through higher use of renewable energy and activation of plant physiological functions.
\end{abstract}

Key words: green farming; organic plant management; energy use efficiency; soil quality; potato

\section{IZVLEČEK}

\author{
OVREDNOTENJE NABORA EKOLOŠKIH \\ POSTOPKOV V INTEGRIRANI PRIDELAVI \\ KROMPIRJA (Solanum tuberosum L.) V PRIMERJAVI S \\ KONVENCIONALNO GLEDE NA PRIDELEK, \\ KAKOVOST, ENERGETSKO UČINKOVITOST IN \\ EKONOMIČNOST
}

$\mathrm{Za}$ ovrednotenje nabora praks ekološkega kmetovanja $\mathrm{v}$ integrirani pridelavi ("zeleno kmetovanje") v primerjavi s konvencionalno je bila $\mathrm{v}$ sezonah 2014-16 opravljena raziskava v Zahodni Bengaliji, Indija. Za pripravo tal je bil pri integrirani pridelavi uporabljen kompost skupaj z mineralnimi gnojili, pri ekološkem kmetovanju sta oskrba rastlin in nadzor škodljivcev sledila "Inhana" tehniki umnega kmetovanja (IRF). Raziskava je pokazala, da so bili večji pridelek (9.7 \%), večja učinkovitost izrabe hranil in večja ekonomska vzdržnost doseženi pri integrirani pridelavi ne glede na mesto raziskave in sorto krompirja. Večje vrednosti kakovostnih kazalcev kot so vsebnost škroba, vitamina $\mathrm{C}, \mathrm{pH}$ int. pri integrirani pridelavi bi lahko bile posledica ekološke obravnave rastlin, ki je ugodno vplivala na biokemične procese $\mathrm{v}$ rastlinah. Izboljšanje kakovosti tal, ki je bilo opaženo pri integrirani pridelavi, bi lahko bilo posledica uporabe na kmetijah pridelanega komposta, ki je vseboval bogato, samovzniklo mikrofloro ( $10^{16}$ na enoto kolonije). Raziskava je pokazala, da lahko integrirana pridelava služi kot učinkovit nadomestek konvencionalnemu kmetovanju glede stalnosti pridelka, preprečevanja zastrupitve hrane in kakovosti končnih proizvodov preko večje uporabe obnovljive energije in vzpodbujanja fizioloških procesov v rastlinah.

Ključne besede: integrirana pridelava; ekološka oskrba rastlin; učinkovitost izrabe energije; kakovost tal; krompir

\footnotetext{
1 * Inhana Organic Research Foundation (IORF) 168 Jodhpur Park, Kolkata-700068, West Bengal, India, corresponding author: antarasea177@gmail.com

2 Department of Agronomy, Bidhan Chandra Krishi Viswavidyalaya, Mohanpur, Nadia, West Bengal 741252, India

3 Dept. of Agronomy, Visva Bharati University, Santiniketan, Bolpur, West Bengal 731235, India

4 Dept. of Agricultural Chem \& Soil Science, Visva Bharati University, Santiniketan, Bolpur, West Bengal 731235, India
} 


\section{INTRODUCTION}

Potato (Solanum tuberosum L.) has emerged as fourth most important food crop in India after rice, wheat and maize (Ojha \& Saha, 2014); sharing 20.32 million ha area with an average production of 46.61 million metric tons. However, with the changing climatic patterns and declining soil productivity indications are ripe that use of only chemical fertilizers cannot ensure sustained production of the crop (Mollah et al., 2011). At the same time producing adequate quantity of good quality organic manure to support crop nutrition is a challenging task under large scale organic farming and practically unviable for resource poor farmers.

Integration of organic manure and inorganic sources of nutrient is necessary for sustainable agriculture as it not only provides greater stability in production, but also helps in restoration and maintenance of soil fertility (Nambiar, 1998). Considering that synthetic compounds especially pesticides have detrimental impact on soil and surrounding ecology; reducing dependency on fertilizers and adopting alternative means for control of pest/disease will help to control over the issues like residual toxicity, ecological imbalance, destruction of soil micro/macro fauna, etc..
Inhana Rational Farming (IRF) Technology, an organic package of practice developed by an Indian Scientist, Dr. P. Das Biswas, has been widely adopted in reputed organic tea estates in India and has shown its effectiveness towards both yield sustenance and soil quality development (Barik et al., 2014b; Chatterjee et al., 2014 and Bera et al., 2014a). Simultaneously conventional tea estates have adopted the technology towards reduction of chemical/ pesticide load and management of recurrent disease problems. In the agriculture sector, the technology has been successfully used for organic production of a variety of crops like paddy, baby corn, green-gram, cabbage, okra, tomato and black-gram, etc. In the present study, the potential of IRF Technology was evaluated towards integrated potato cultivation. Here integrated crop management has been termed as green farming as synthetic inputs for plant application that are the major cause of health hazards and disfunctional ecology; could be completely avoided through adoption of IRF plant management schedule. Performance in terms of crop productivity, quality, energy consumption and economics was adjudged in comparison to conventional crop management.

\section{MATERIALS AND METHODS}

\subsection{Study area}

The present study was undertaken during the crop season of 2014- 15 and 2015- 16 at two pilot sites. Pilot Area I- Mathurapur village of North 24 Paraganas district (Figure 1) and Pilot Area II- Bhabanipur village of Nadia district (state West Bengal, India). At initiation, farmers' meetings were conducted to select progressive volunteer farmers (Figure 2). Local governing bodies also extended their support in terms of infrastructure and other necessary components that were required for successful completion of the study.

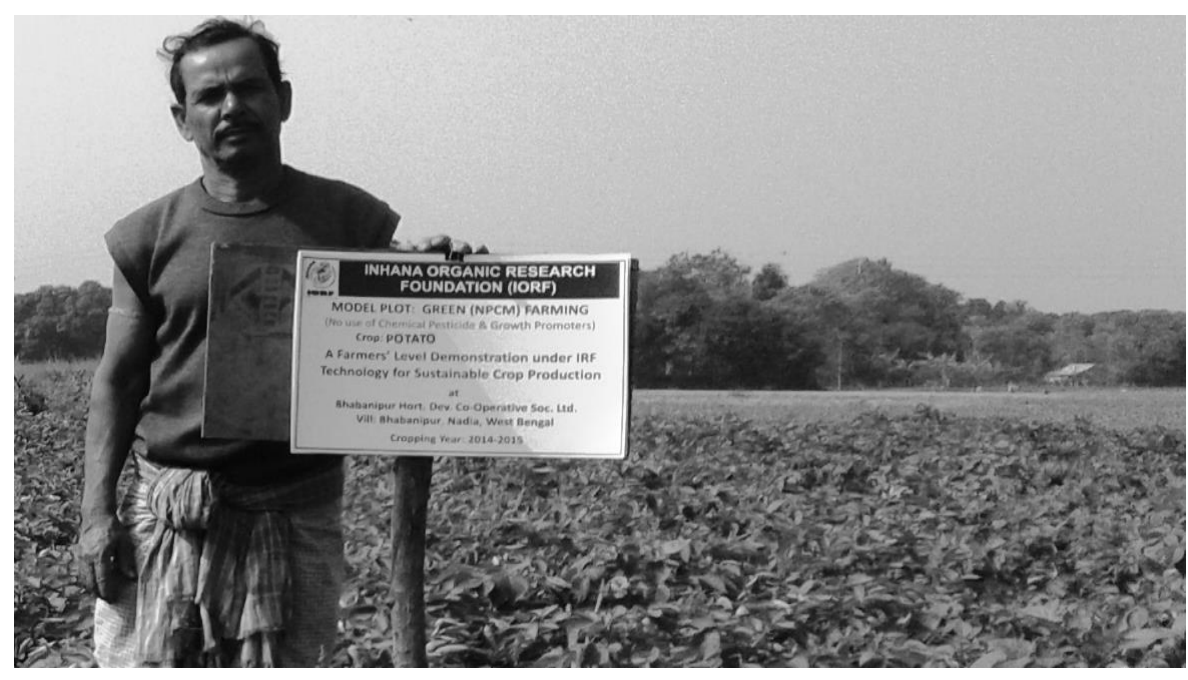

Figure 1: Project farmer in green farming plot in Pilot area- II. 


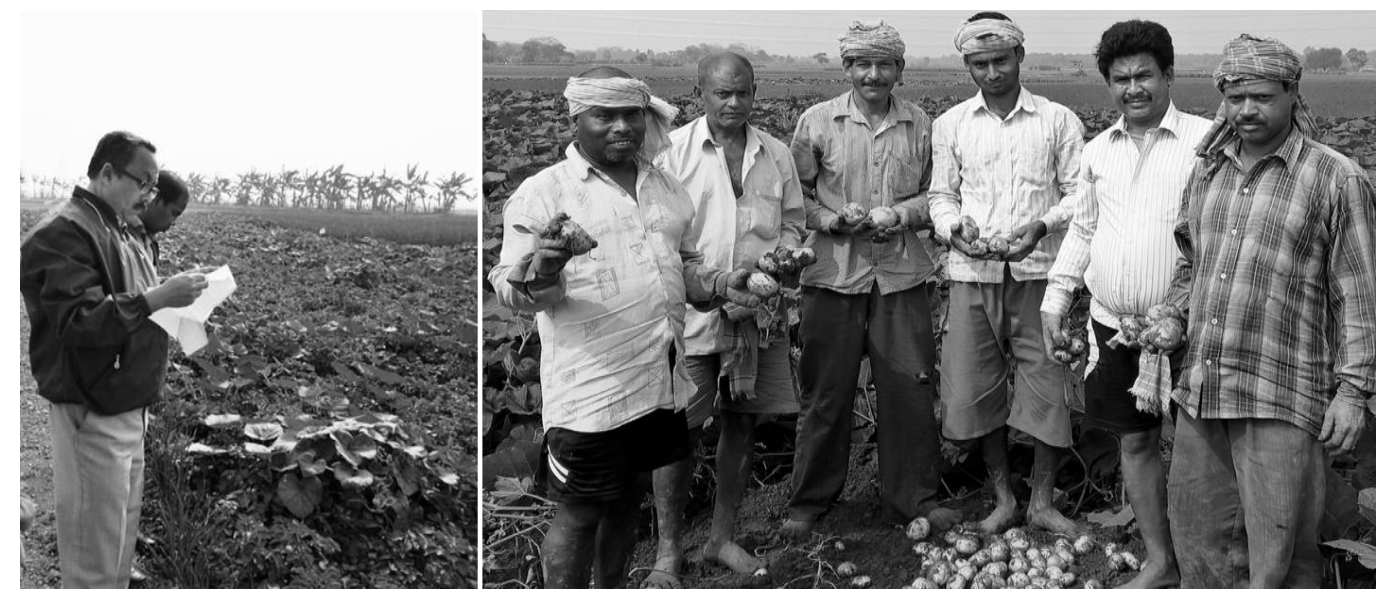

Figure 2: Prof. Kajal Sengupta (Head, Dept. of Agronomy, BCKV, State Agricultural University) and the Project farmers in the study area.

\subsection{The hypothesis}

Organic soil management is necessary for restoring soil health, which is pre-requisite for sustenance of yield. But it will take time until the desired developments are obtained, considering that resource scarcity forms the major bottle neck towards its adoption in wider scale. In this aspect adoption of organic plant managements towards re-activation of bio-chemical functions can directly compliment plant health while indirectly ensuring lesser pest interference; as pest starve on healthy plants (Paull, 2007).According to the trophobiosis theory of F. Chaboussou (Chaboussou, 2004), pest and disease set in with increase in free amino acids and reducing sugars pools in plant cell sap. The phenomenon usually occurring whenever plant metabolism becomes impaired due to biotic and abiotic factors, excess fertilization specially with nitrogenous fertilizers and application of systemic fungicides/pesticides etc. (Dias, 2012).Hence, better plant health vis-a-vis lesser pest incidence along with supportive soil functions can ensure the crop objective and economic balance in agriculture (Figure 3).

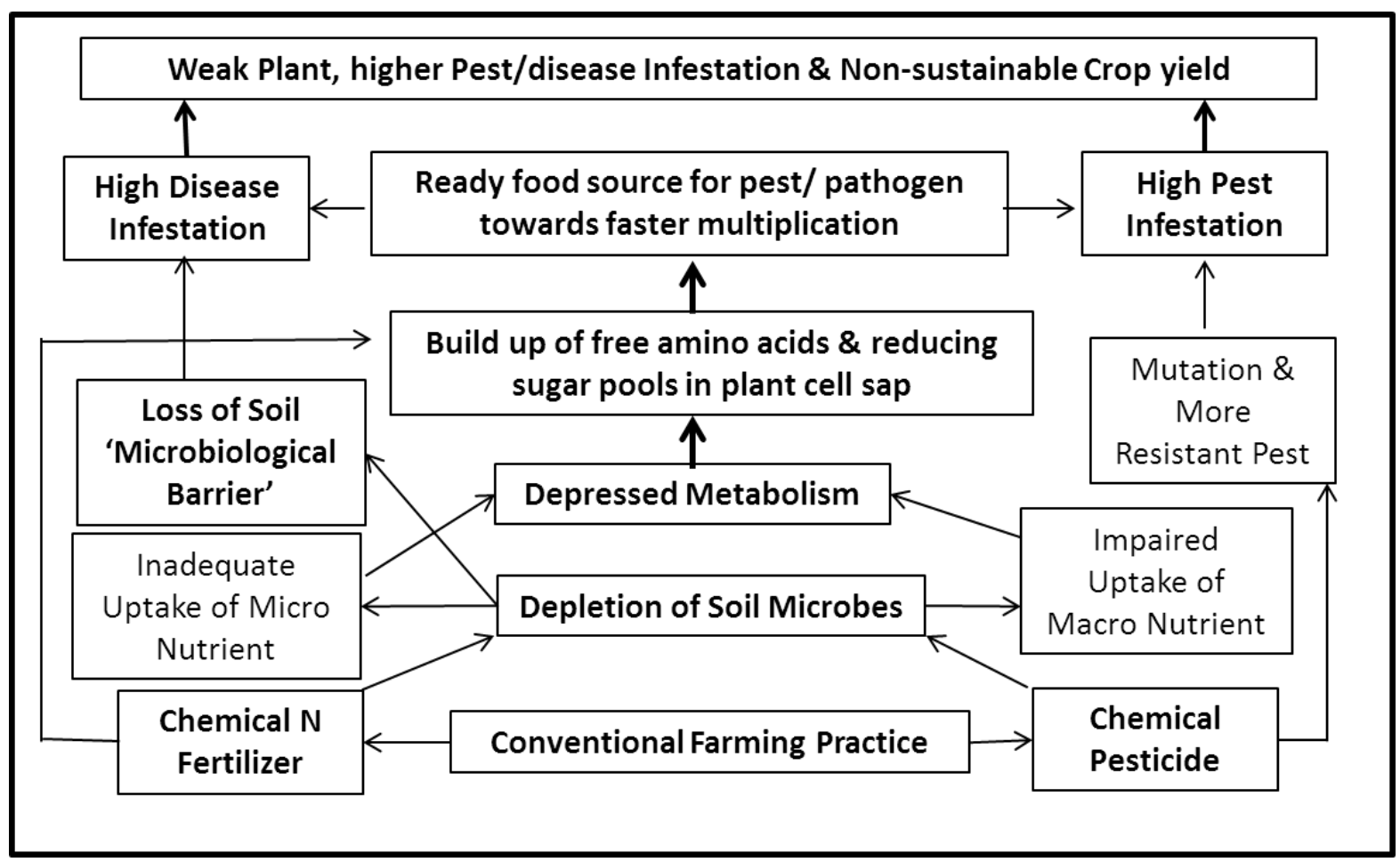

Figure 3: Flow diagram of plant - pest/disease relationship under conventional crop management as per Trophobiosis Theory of F. Chaboussou 


\subsection{Inhana Rational Farming Technology}

Inhana Rational Farming (IRF) Technology developed by an Indian scientist (Dr. P. Das Biswas), associated with organic research for the last 15 years; has a holistic approach where interrelated and integrated relationships of all components of the ecosystem i.e. soil, plant and the surrounding environment are taken into consideration. It provides the right environment for all the components, be it a plant or soil, which leads to ecological improvement thereby ensuring economic sustainability (Barik et al., 2014a). The technology strives towards (i) energization of soil system i.e., to enable soil to function as an effective growth medium for plants and (ii) energization of the plant system i.e., to enable efficient extraction, utilization and assimilation of nutrients and enhancement of biochemical and structural defense leading to activation of the plants' host defense mechanism (Bera et al., 2014a).

\subsection{Cultivation details}

Three potato (Solanum tuberosum L.) varieties 'Kufri Chandramukhi', 'Super - 6' and 'Kufri Jyoti' were taken for the study. The experiment was laid out in randomized block design (RBD) and potato varieties Super -6 and Kufri Jyoti were used in pilot Area-I (Mathurapur village) while 'Kufri Chandramukhi' and 'Kufri Jyoti' were used in Pilot Area-II (Bhabanipur village) (Figure 1). Tubers were planted during $10^{\text {th }}$ to $20^{\text {th }}$ November $(2014-15)$ and harvested during $20^{\text {th }}$ February to $2^{\text {nd }}$ March (2015-16). Planting was done at the rate of $750 \mathrm{~kg}$ tuber ha ${ }^{-1}$. A distance of $60 \mathrm{~cm}$ from row to row and $25 \mathrm{~cm}$ from plant to plant was maintained. One seedling was planted in each hill. In the conventional crop management (CCM) plots, 1500 $\mathrm{kg}$ complex fertilizer (10: 26: 26), $375 \mathrm{~kg}$ urea and 225 $\mathrm{kg}$ muriate of potash (MOP) were applied per hectare as per recommended practice. In case of green farming plots, $15 \mathrm{t}$ of Novcom compost and $375 \mathrm{~kg}$ complex fertilizer (10:26:26) were applied per hectare.

In the green farming plots, full dose of compost and half dose of complex fertilizer were applied during final land preparation. Remaining complex fertilizer (10: 26: 26) was applied at the side row and covered with soil about 30-35 days post planting i.e., at the time of earthing up, followed by irrigation at $12-15,30-35$, and 45-50 DAP. In CCM plot, two third of total complex fertilizer (10: 26: 26), full dose of MOP and one- half of urea were applied at the time of final land preparation. Remaining urea, complex fertilizer and irrigation were applied as in green farming plots. Different intercultural operations were done in all the plots to ensure normal growth of the crops.

In case of green farming potato seed tubers were treated with Inhana seed solution. 1.51 solution was used for $750 \mathrm{~kg}$ of tubers, for planting one hectare area. Mancozeb (75\% WP) was used for tuber treatment, $2.5 \mathrm{~g} / \mathrm{l}$ water $/ \mathrm{kg}$ tuber under CCM.

Prophylactic spray for disease control i.e., late blight was carried out in case of both treatments. In CCM plots two rounds of copper oxychloride (50 WDP) was sprayed, 1 1/ha 60 and 75 days after transplanting. Under green farming ten rounds of spraying were given from 2 to 3 leaf stage using various Inhana Solutions (Table 1 and 2), at 7 to 10 days interval.

All the recommended cultural practices were adopted during the course of experimentation. The crop haulm was cut after 100 days of planting. The treatments were harvested after ten days of haulm-cutting to allow tuber curing in the field. 
Evaluation of an organic package of practice ... farming in terms of yield, quality, energy efficiency and economics

Table 1: Solutions used under IRF Plant Management Package for Green Farming

Sl. No Solution Name

Dose \& Dilution

\section{Growth stage}

(time of application)

1. Seed treatment solution

1.5 litre for tuber for Tubers were kept for 15-20 minutes in the planting one hectare, diluted solution in shade for 5-10 minutes, diluted in 1500 litre followed by planting in the field.

water.

\section{Post Sprouting Plant Management}

1. $\quad \mathrm{IB}(\mathrm{Ag})-2+\mathrm{IB}(\mathrm{Ag})-7$

$(1.51+1.51) /$ hectare

To be sprayed on plants, at $7^{\text {th }}$ day post sprouting.

2. $\mathrm{IB}(\mathrm{Ag})-12+\mathrm{IB}(\mathrm{Ag})-7$

$(1.51+1.51) /$ hectare

$14^{\text {th }}$ day post sprouting.

3. $\mathrm{IB}(\mathrm{Ag})-4$

$1.51 /$ hectare

$21^{\text {st }}$ day post sprouting.

4. $\quad \mathrm{IB}(\mathrm{Ag})-11$

$1.51 /$ hectare

$28^{\text {th }}$ day post sprouting.

5. $\mathrm{IB}(\mathrm{Ag})-1$

$1.51 /$ hectare

$35^{\text {th }}$ day post sprouting

6. $\mathrm{IB}(\mathrm{Ag})-2+\mathrm{IB}(\mathrm{Ag})-7+\mathrm{IB}$

$(1.51+1.51+1.51) /$

$42^{\text {nd }}$ day post sprouting (Ag) -11

hectare

7. IB $(\mathrm{Ag})-3$

$1.51 /$ hectare

$49^{\text {th }}$ day post sprouting

8. $\mathrm{IB}(\mathrm{Ag})-12+\mathrm{IB}(\mathrm{Ag})-7$

$(1.51+1.51) /$ hectare

$56^{\text {th }}$ day post sprouting.

9. $\mathrm{IB}(\mathrm{Ag})-2+\mathrm{IB}(\mathrm{Ag})-7$

$1.51+1.51) /$ hectare

$63^{\text {rd }}$ day post sprouting.

10. $\quad \mathrm{IB}(\mathrm{Ag})-10$

$1.51 /$ hectare

$70^{\text {th }}$ day post sprouting.

Note: Details regarding Solutions under IRF Package of Practice has been given by Chatterjee et al., (2014), Barik et al., (2014a; 2014b) and Bera et al., (2014a) 
Table 2: Ingredients used in Inhana solutions and their role in crop production

1. Seedtuber treatment solution: The solution is biologically activated and potentized extract of Calotropis procera R. and Tinospora crispa Miers. It plays a major role in initiation of metabolic resources during germination, faster independence of plants from the tuber reserve, photosynthesis enhancement and increased uptake of organic and inorganic solutes through roots.

2. IB (Ag) - 1: The solution is biologically activated and potentized extract of Hyoscyamus niger L., Ficus benghalensis L. and Dendrocalamus strictus Nees. It acts as an organic growth promoter, activator and regulator. It energizes and stimulates the plant system for best use of soil nutrients (both applied and stored). It also regulates every stage of the grand growth period influencing growth correlation.

3. IB (Ag) - 2: The solution is biologically activated and potentiated extract of Ocimum sanctum L., Calotropis procera R. and Cynodon dactylon (L.) Pers. It activates plants' host defense mechanism through silica management providing structural defense against fungal pathogens. It also stimulates plants' immune system by activating the biosynthesis of different phenolic compounds having fungi-toxic property.

4. IB (Ag) - 3: The solution is biologically activated and potentiated extract of Adhatoda vasica Nees., Zingiber officinale Roscoe and Embelia ribes Burm. F. It acts as an organic solution for potassium absorption and utilization. It increases the efficiency of potassium uptake through energized root capacity so that gradual reduction in application is ensured. At the same time it activates suction pressure by influencing diffusion pressure deficit.

5. IB (Ag) - 4: The solution is biologically activated and potentiated extract of Calotropis procera R., Dendrocalamus strictus Nees. and Bombax malabaricum D.C. It ensures direct biological absorption and utilization of atmospheric-N by plant. It also balances the quantity of nitrogen within plant system at the right time, thereby preventing deleterious effect on quality of the produce.

6. IB(Ag ) - 7: The solution is biologically activated and potentiated extract of Ocimum sanctum L. It stimulates root function, activates root growth/ penetration and energizes soil in the root zone; thus improving soil-plant relationship. It helps to develop soil CEC, energizes the production of micro-flora and bio-flora around the root zone, improves base saturation to the desired level and enhances root cation exchange capacity. It stimulates root growth and penetration by activating contact exchange capacity of root.

7. IB (Ag) - 10: The solution is biologically activated and potentiated extract of Costus speciosus Sm. and Tylophora indica (Burm. f.) Merrill. It helps to improve plant transport by delivering essential substances for various internal functions.

8. $\quad \mathbf{I B}(\mathbf{A g})$ - 11: The solution is biological activated and potentiated extract of Solanum xanthocarpum Schrad. \& Wendl. and Aristolochia indica L.. It helps to improve the movement of solutions by providing systemic presence to give structural integrity.

9. IB (Ag) - 12: The solution is biological activated and potentiated extract of Sida cordifolia Linn. and Berberis asiatica Roxb. ex. DC . It helps to improve plant's capacity for starch synthesis.

\subsection{Research methodology}

Compost for green farming plots was produced on-farm within a period of 21 days; from poultry litter and cow dung; using Novcom composting method. Detailed procedure was documented by Seal et al. (2015) while studying quality of Novcom compost from poultry litter. Twelve compost quality parameters were studied as per the procedure described by Seal et al. (2012). Final compost samples appeared dark brown in colour with earthy smell, deemed necessary for mature compost (Epstein, 1997). Average moisture in compost samples varied from 58.76 to 65.15 percent (Table 3 ). $\mathrm{pH}$ values of the Novcom (poultry litter) compost samples varied from $6.89-7.23$. Organic carbon content in the compost samples varied from 22.64 to 28.14 percent, qualifying the criteria for field application (16 to 38 percent) as per the standard range (Evanylo, 2006). Total nutrient content in terms of total NPK in the compost sample varied from 4.06 to 4.71 percent. $\mathrm{C} / \mathrm{N}$ ratio varied from 12:1 to $15: 1$, which was within the reference range of $\leq 20$ (FAI, 2007) as suggested for well-matured compost; indicating the compost was mature and suitable for soil application. Microbial population in terms of bacteria, fungi and actinomycetes (expressed in $\log _{10}$ value) in mature compost was 14.373 to 15.237 . Stability of compost was examined 
through study of $\mathrm{CO}_{2}$ evolution rate of compost samples, which was more or less within the stipulated range $(2.0-5.0 \mathrm{mg} \mathrm{CO}-\mathrm{C} / \mathrm{g} \mathrm{OM} /$ day) for stable compost (Trautmann \& Krasny, 1997). The phytotoxicity bioassay test value $(0.89)$ indicated absence of phytotoxic effect in the final compost as suggested by Trautmann \& Krasny, 1997.

Table 3: Quality parameters of Novcom compost

\section{SI. No. Parameter}

Novcom (Poultry Litter) Compost

\begin{tabular}{|c|c|c|c|c|}
\hline 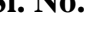 & 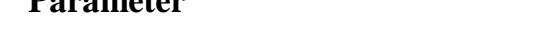 & Range Value & Mean & \pm Std. E. \\
\hline 1. & Moisture percent (\%) & $58.76-65.15$ & 62.10 & \pm 1.02 \\
\hline 2. & $\mathrm{pH}_{\text {water }}(1: 5)$ & $6.89-7.23$ & 7.05 & \pm 0.08 \\
\hline 3. & Electrical conductivity $\left(\mathrm{dSm}^{-1}\right)$ & $2.13-2.39$ & 2.21 & \pm 0.09 \\
\hline 4. & Organic carbon $(\%)$ & $22.64-28.14$ & 25.87 & \pm 1.10 \\
\hline 6. & Total NPK (\%) & $4.06-4.71$ & 4.13 & \pm 0.21 \\
\hline 7. & $\mathrm{C} / \mathrm{N}$ ratio & $12: 1-15: 1$ & $13: 1$ & \pm 0.43 \\
\hline 8. & Total bacterial count ${ }^{2}$ & $15.032-15.237$ & 15.201 & \pm 1.01 \\
\hline 9. & Total fungal count ${ }^{2}$ & $14.373-15.047$ & 15.043 & \pm 0.65 \\
\hline 10. & Total actinomycetes count ${ }^{2}$ & $14.573-14.843$ & 14.763 & \pm 0.53 \\
\hline 11. & $\begin{array}{l}\mathrm{CO}_{2} \text { evolution rate } \\
\text { (mgCO }-C / g \text { organic carbon/day) }\end{array}$ & $2.13-3.58$ & 2.71 & \pm 0.08 \\
\hline 12. & $\begin{array}{l}\text { Germination index } \\
\text { (phytotoxicity bioassay) }\end{array}$ & $0.83-0.96$ & 0.89 & \pm 0.01 \\
\hline
\end{tabular}

${ }^{2}$ Microbial count : colony forming unit c.f.u. per g moist compost expressed as $\log _{10}$ value

For measurement of agronomic parameters, ten plants per plot were selected at random, and marked for height measurement. Plant emergence was recorded at 30 DAP. Observations on plant height, number of shoots and leaves per plant were recorded at 60 DAP. Height of the tallest shoot was measured from the soil surface to the base of last leaf unfolded at 60 DAP. Number and mass of total tubers were recorded at harvest. In order to find out if there were significant differences among treatments; Duncan's Multiple Range Test (DMRT) was used for analyzing data collected on apparent growth (plant height, number of leaves) and yield parameters (tuber count and tuber mass). Pre and post experiment surface soil samples $(0-25 \mathrm{~cm})$ were collected and analysed for soil physico-chemical properties, nutrient content and biological properties following standard methodologies (Black, 1965; Jackson, 1973).

Soil Development Index (SDI) was calculated taking eleven soil quality parameters viz. $\mathrm{pH}$, organic carbon, available $\mathrm{N}, \mathrm{P}, \mathrm{K}$ and $\mathrm{S}$, soil MBC, soil-FDA, qMBC, $\mathrm{qCO}_{2}$ and $\mathrm{qFDA}$ as per following equation.

n Soil Development Index (SDI)
$\begin{aligned} & \text { (Bera et al. 2013a) } \\ & \text { ( }\end{aligned}$

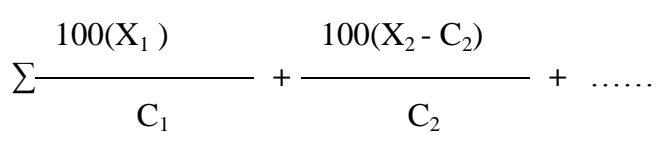

$\mathrm{n}=1$

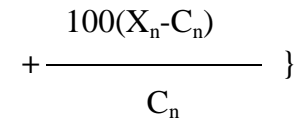

$\mathrm{C}_{\mathrm{n}}$

Where $\mathrm{X}=$ Value of Individual Soil Quality Parameter after Experimentation, $\mathrm{C}=$ Value of Individual Soil Quality Parameters before Experimentation; $\mathrm{a}=$ no. of Soil Quality Parameters showing increase over initial value. In case of $\mathrm{qCO}_{2}$, a modification $\left[-1 \times\left(X_{n}-C_{n}\right) / C_{n}\right]$ in the formula is taken, as decrease of $\mathrm{qCO}_{2}$ is considered to be good for soil health. 
Different physicochemical analyses were done for determining potato quality. Specific gravity was determined by standard water displacement method (Raj et al., 2011). Starch and pH content was assessed as per method of Widmann et al., 2008 and Feltran et al., (2004) respectively. Titratable acidity and vitamin C were adjudged using the methods of Sadasivam \& Manickam, 2011.
Energy equivalence of inputs and output was sourced from Khan \& Hossain (2007); Zangeneh et al. (2010) and Zahedi et al. (2014). Energy use efficiency, energy productivity, specific energy, energy intensiveness and net energy were calculated as per the methodology of Banaeian et al. (2010) and Ghorbani et al. (2011).The economics of various treatments was also worked out following standard techniques (Gomez \& Gomez, 1984).

\section{RESULTS AND DISCUSSION}

\subsection{Growth and yield attributes}

Emergence percent varied within 93.3 and 98.8 per cent in CCM plots and 96.3 to 99.8 in green farming plots (Table 4). Slightly higher (non significant difference) emergence in case of the latter may influence the sprouting potential of potato tubers. Planting of well sprouted healthy seed tubers, provided favourable condition for emergence (Bhatia et al., 1992).

Plant height and number of compound leaves per plant at 60 days of crop growth varied significantly under the studied farming systems. Maximum (average) plant height of 56.2 and $57.1 \mathrm{~cm}$ with a maximum (average) 56.6 and 59.3 leaves per plant under green farming was well above the values (49.6 and $50.7 \mathrm{~cm}$ plant height with 50.2 and 57.5 leaves per plant) as recorded for
CCM plots. The results may indicate efficient plant metabolic functions and soil nutrient mineralization under organic plant management (using IRF Technology) and soil application of Novcom compost. Almost identical impact was documented by Barik et al. (2014a; 2014b) and Bera et al. (2014b), while working with other crops. Similar trend of results were also observed in case of tuber and number of tubers above processing grade (> $45 \mathrm{~mm}$ ). As per Venkatasalam et al. (2012), addition of organic manure significantly influenced the beneficial microorganisms to colonize in rhizosphere and stimulate plant growth by providing necessary nutrients besides synthesizing some plant hormones; which may be the reason for increase in plant height, number of leaves and tuber mass, irrespective of potato variety. 
Table 4: Growth attributes of potato under studied farming systems (as average of both seasons)

\begin{tabular}{|c|c|c|c|c|c|c|}
\hline \multirow[b]{2}{*}{ Treatment } & \multirow[b]{2}{*}{ Potato Variety } & \multirow[b]{2}{*}{ Emergence $(\%)$} & \multirow[b]{2}{*}{$\begin{array}{l}\text { Plant height } \\
\qquad(\mathrm{cm})\end{array}$} & \multirow[b]{2}{*}{$\begin{array}{l}\text { No. of compound } \\
\text { leaves /plant }\end{array}$} & \multicolumn{2}{|c|}{$\begin{array}{l}\text { No. of tuber } \\
\text { (thousand/ha) }\end{array}$} \\
\hline & & & & & $\begin{array}{l}\text { Processing } \\
\text { Grade } \\
(>45 \mathrm{~mm})\end{array}$ & Total \\
\hline \multicolumn{7}{|c|}{ Pilot Area I: Mathurapur village (district: North 24 Paraganas), West Bengal, India } \\
\hline $\begin{array}{l}\text { Conventional } \\
\text { Crop }\end{array}$ & KufriJyoti & $\begin{array}{c}93.3-96.8 \\
\left(95.1^{\circ}\right)[ \pm 4.91]\end{array}$ & $\begin{array}{c}43.3-49.8 \\
(45.5)[ \pm 2.53]\end{array}$ & $\begin{array}{c}44.2-46.8 \\
\left(44.6^{c}\right)[ \pm 2.13]\end{array}$ & $294.69^{\mathrm{b}}$ & $539.7^{\mathrm{b}}$ \\
\hline $\begin{array}{l}\text { Management } \\
(\mathrm{CCM})\end{array}$ & $\begin{array}{l}\text { KufriChandramu } \\
\text { khi }\end{array}$ & $\begin{array}{c}93.7-97.1 \\
\left(95.6^{c}\right)[ \pm 5.03]\end{array}$ & $\begin{array}{c}46.7-54.1 \\
(49.6)[ \pm 2.11]\end{array}$ & $\begin{array}{c}48.3-54.4 \\
\left(50.2^{\mathrm{b}}\right)[ \pm 2.37]\end{array}$ & $275.67^{\mathrm{c}}$ & $501.45^{\mathrm{c}}$ \\
\hline \multirow[t]{2}{*}{$\begin{array}{l}\text { Green Farming } \\
\text { utilizing IRF }\end{array}$} & KufriJyoti & $\begin{array}{c}97.5-99.8 \\
\left(98.6^{a}\right)[ \pm 4.13]\end{array}$ & $\begin{array}{c}43.7-52.8 \\
(48.1)[ \pm 2.05]\end{array}$ & $\begin{array}{c}44.8-53.7 \\
\left(50.3^{b}\right)[ \pm 2.76]\end{array}$ & $325.53^{\mathrm{a}}$ & $586.74^{\mathrm{a}}$ \\
\hline & $\begin{array}{l}\text { KufriChandramu } \\
\text { khi }\end{array}$ & $\begin{array}{c}97.1-99.4 \\
\left(97.7^{\mathrm{ab}}\right)[ \pm 4.11]\end{array}$ & $\begin{array}{c}47.1-59.3 \\
(56.2)[ \pm 2.09]\end{array}$ & $\begin{array}{c}49.6-59.8 \\
\left(56.6^{\mathrm{a}}\right)[ \pm 2.14]\end{array}$ & $287.25^{\mathrm{bc}}$ & $529.23^{\mathrm{b}}$ \\
\hline \multicolumn{7}{|c|}{ Pilot Area II: Bhabanipur village, (district: Nadia), West Bengal, India } \\
\hline $\begin{array}{l}\text { Conventional } \\
\text { Crop }\end{array}$ & KufriJyoti & $\begin{array}{c}94.3-98.8 \\
\left(96.8^{\mathrm{ns}}\right)[ \pm 5.88]\end{array}$ & $\begin{array}{c}44.3-51.8 \\
\left(48.8^{\mathrm{d}}\right)[ \pm 2.09]\end{array}$ & $\begin{array}{c}43.7-54.8 \\
\left(47.5^{c}\right)[ \pm 1.71]\end{array}$ & $263.27^{\mathrm{d}}$ & $494.44^{\mathrm{d}}$ \\
\hline $\begin{array}{l}\text { Management } \\
(\mathrm{CCM})\end{array}$ & Super 6 & $\begin{array}{c}95.2-98.4 \\
\left(96.5^{\text {ns }}\right)[ \pm 5.44]\end{array}$ & $\begin{array}{c}49.3-53.8 \\
\left(50.7^{\mathrm{c}}\right)[ \pm 2.01]\end{array}$ & $\begin{array}{c}48.7-63.4 \\
\left(57.5^{\mathrm{ab}}\right)[ \pm 2.23]\end{array}$ & $302.13^{\mathrm{b}}$ & $543.24^{\mathrm{b}}$ \\
\hline \multirow[t]{2}{*}{$\begin{array}{l}\text { Green Farming } \\
\text { utilizing IRF }\end{array}$} & KufriJyoti & $\begin{array}{c}96.5-99.2 \\
\left(97.4^{\mathrm{ns}}\right)[ \pm 4.79]\end{array}$ & $\begin{array}{c}46.2-59.5 \\
\left(54.4^{b}\right)[ \pm 2.12]\end{array}$ & $\begin{array}{c}43.3-53.5 \\
\left(46.5^{\mathrm{c}}\right)[ \pm 2.19]\end{array}$ & $285.46^{\mathrm{c}}$ & $530.13^{\mathrm{bc}}$ \\
\hline & Super 6 & $\begin{array}{c}96.3-98.3 \\
\left(96.3^{\text {ns }}\right)[ \pm 4.75]\end{array}$ & $\begin{array}{c}48.3-59.8 \\
\left(57.1^{\mathrm{a}}\right)[ \pm 2.13]\end{array}$ & $\begin{array}{c}50.4-65.3 \\
\left(59.3^{\mathrm{a}}\right)[ \pm 2.12]\end{array}$ & $365.34^{\mathrm{a}}$ & $631.13^{\mathrm{a}}$ \\
\hline
\end{tabular}

Note: Figure in parenthesis ( ) represents mean value \& Standard Error [士 ]. The means marked with different letters in the same column were significantly different at $P<0.05$ under Duncan's New Multiple Range Test.

Nutrient Use Efficiency (NUE) in terms of 'Partial Factor Productivity' of applied nutrients $\left(\mathrm{PFP}_{\mathrm{NPK}}\right)$; were evaluated for both CCM and green farming plots. The advantage of $\mathrm{PFP}_{\mathrm{NPK}}$ is that it quantifies total economic output from any particular factor/nutrient, relative to its utilization from all resources in the system, including indigenous soil nutrients and nutrients from applied inputs (Cassman et al., 1996). Decline in $\mathrm{PFP}_{\mathrm{NPK}}$ may be attributed to nutrient imbalance, decline in indigenous soil-NPK supply, subsoil compaction, reduced root volume and increased incidence of pests and diseases (Karim \& Ramasamy, 2000). Adoption of efficient NPK management practices is responsible for higher partial factor productivity (Yadav, 2003). The value was found to be significantly higher in green farming plots as compared to CCM (Table 5). 20.61 to $23.03 \mathrm{~kg}$ and
63.01 to $74.93 \mathrm{~kg}$ potato per $\mathrm{kg}$ NPK, were recorded under CCM and green farming plots respectively. Higher value in case of the later treatment may be attributed to adoption of organic plant management (using IRF).

Evaluation of grade wise tuber distribution revealed higher production of large (>75 g) and medium sized $(50-75 \mathrm{~g})$ tubers under green farming (13.6 and $25.5 \%$ respectively). This may be due to cumulative effect of organic and inorganic fertilizers sources (Mandal et al., 2005) as well as organic plant management (Figure 4). Higher bulking of tubers under integrated soil management was corroborated with the finding of Sharma et al. (1996). 


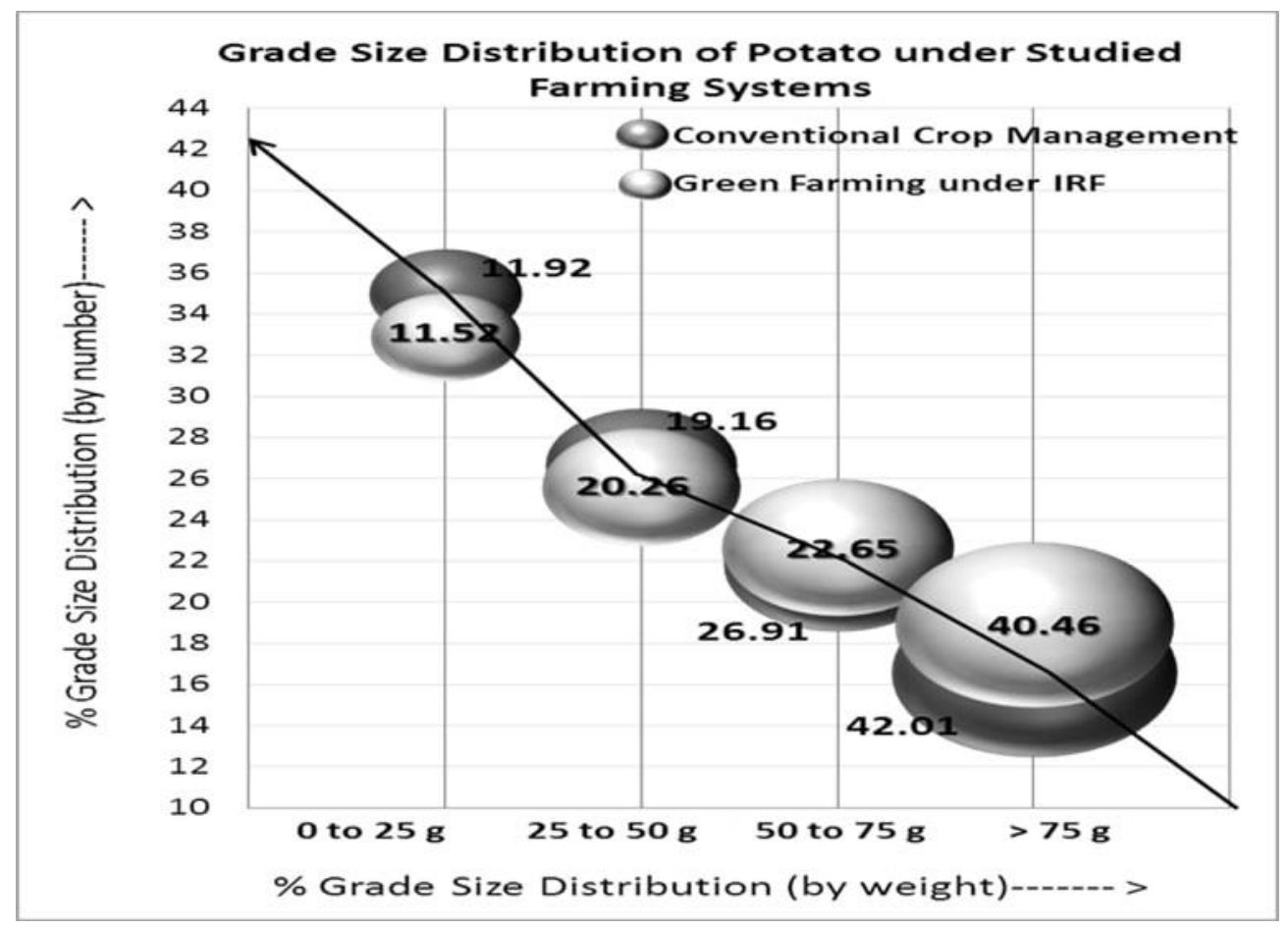

Figure 4: Grade wise distribution of potato tubers (number and mass) under CCM and Green Farming

Production of large sized tubers vis-à-vis higher yield would reflect efficient photosynthesis, phloem loading and translocation as well as synthesis of large molecular weight substances within storage organs (Singh, 1999). Hence, the observed phenomenon under green farming may indicate the positive influence of organic plant management (utilizing IRF) towards rapid bulking of tubers.

Maximum tuber yield was obtained from variety Super6 (33.0 t/ha) followed by 'Kufri Jyoti' (30.00 t/ha) in green farming plots, at Pilot Area II and I respectively.
In both the Pilot Areas minimum tuber yield was obtained in CCM plots irrespective of potato variety (Table 5). Mohapatra et al. (2008) and Kumar et al. (2011) also reported improvement in tuber yield of potato with application of organic manure. Hence better yield performance in the green farming plots may be attributed to the release of organic acids following compost application which led to proper nutrient mineralization (Kumar et al., 2011) vis-à-vis organic plant management, which enabled adequate nutrient uptake (Kumar et al., 2008). 
Evaluation of an organic package of practice ... farming in terms of yield, quality, energy efficiency and economics

Table 5: Nutrient Use Efficiency (NUE) and yield attributes under studied farming systems (as average of both seasons)

\begin{tabular}{|c|c|c|c|c|c|c|c|}
\hline \multirow[t]{2}{*}{ Treatment } & \multirow[t]{2}{*}{ PotatoVariety } & $\begin{array}{l}\mathrm{NUE}^{*} \\
(\mathrm{~kg} / \mathrm{kg}\end{array}$ & \multicolumn{4}{|c|}{$\begin{array}{c}\text { Grade wise number } \\
\text { [ mass }(\mathrm{kg}) \text { of the tubers } / \mathrm{ha}]\end{array}$} & \multirow{2}{*}{$\begin{array}{l}\text { Total tuber } \\
\text { yield (t/ha) }\end{array}$} \\
\hline & & NPK) & $0-25 \mathrm{~g}$ & $25-50 \mathrm{~g}$ & $50-75 \mathrm{~g}$ & $>75 \mathrm{~g}$ & \\
\hline \multicolumn{8}{|c|}{ Pilot Area I: Mathurapur village (district: North 24 Paraganas), West Bengal, India } \\
\hline \multirow{2}{*}{$\begin{array}{l}\text { Conventional } \\
\text { Crop } \\
\text { Management } \\
(\mathrm{CCM})\end{array}$} & KufriJyoti & $22.42^{\mathrm{c}}$ & $\begin{array}{c}184577^{\mathrm{bc}} \\
{[3402]}\end{array}$ & $\begin{array}{c}141283^{b} \\
{[5041]}\end{array}$ & $\begin{array}{c}113914^{b} \\
{[7452]}\end{array}$ & $\begin{array}{l}99925^{b} \\
{[11855]}\end{array}$ & $27.75^{\mathrm{b}}$ \\
\hline & $\begin{array}{l}\text { KufriChandramu } \\
\text { khi }\end{array}$ & $21.21^{\mathrm{c}}$ & $\begin{array}{c}184478^{\mathrm{bc}} \\
{[3300]}\end{array}$ & $\begin{array}{c}135447^{\mathrm{c}} \\
{[5043]}\end{array}$ & $\begin{array}{c}105881^{\mathrm{bc}} \\
{[6668]}\end{array}$ & $\begin{array}{l}75644^{d} \\
{[11239]}\end{array}$ & $26.25^{\mathrm{bc}}$ \\
\hline \multirow[t]{2}{*}{$\begin{array}{l}\text { Green Farming } \\
\text { utilizing IRF }\end{array}$} & KufriJyoti & $68.12^{\mathrm{a}}$ & $\begin{array}{c}189001^{\mathrm{a}} \\
{[3457]^{-}}\end{array}$ & $\begin{array}{r}151320^{\mathrm{a}} \\
{[6549]}\end{array}$ & $\begin{array}{c}135021^{\mathrm{a}} \\
{[8543]}\end{array}$ & $\begin{array}{l}111398^{\mathrm{a}} \\
{[11451]}\end{array}$ & $30.00^{\mathrm{a}}$ \\
\hline & $\begin{array}{l}\text { KufriChandramu } \\
\text { khi }\end{array}$ & $63.01^{\mathrm{ab}}$ & $\begin{array}{c}182950^{\mathrm{d}} \\
{[3396]}\end{array}$ & $\begin{array}{l}138214^{\mathrm{bc}} \\
{[5511]}\end{array}$ & $\begin{array}{c}118256^{\mathrm{b}} \\
{[7532]}\end{array}$ & $\begin{array}{l}89810^{\mathrm{c}} \\
{[11312]}\end{array}$ & $27.75^{\mathrm{b}}$ \\
\hline
\end{tabular}

Pilot Area II: Bhabanipur village, (district: Nadia), West Bengal, India

\begin{tabular}{|c|c|c|c|c|c|c|c|}
\hline \multirow{2}{*}{$\begin{array}{l}\text { Conventional } \\
\text { Crop } \\
\text { Management } \\
(\mathrm{CCM})\end{array}$} & Kufri Jyoti & $20.61^{d}$ & $\begin{array}{c}181900^{\mathrm{bc}} \\
{[3211]}\end{array}$ & $\begin{array}{c}134240^{\mathrm{cd}} \\
{[5221]}\end{array}$ & $\begin{array}{r}111017^{\mathrm{d}} \\
{[7219]}\end{array}$ & $\begin{array}{l}67283^{\mathrm{d}} \\
{[9849]}\end{array}$ & $25.50^{\mathrm{d}}$ \\
\hline & Super 6 & $23.03^{c}$ & $\begin{array}{c}174445^{\mathrm{d}} \\
{[2927]}\end{array}$ & $\begin{array}{c}142003^{b} \\
{[5352]}\end{array}$ & $\begin{array}{c}123804^{\mathrm{b}} \\
{[7718]}\end{array}$ & $\begin{array}{l}102987^{\mathrm{b}} \\
{[12503]}\end{array}$ & $28.50^{\mathrm{b}}$ \\
\hline \multirow[t]{2}{*}{$\begin{array}{l}\text { Green Farming } \\
\text { utilizing IRF }\end{array}$} & Kufri Jyoti & $63.01^{\mathrm{b}}$ & $\begin{array}{c}183006^{\mathrm{b}} \\
{[3338]}\end{array}$ & $\begin{array}{c}138438^{c} \\
{[5600]}\end{array}$ & $\begin{array}{r}117206^{\circ} \\
{[7868]}\end{array}$ & $\begin{array}{c}91479^{c} \\
{[10944]}\end{array}$ & $27.75^{\mathrm{bc}}$ \\
\hline & Super 6 & $74.93^{\mathrm{a}}$ & $\begin{array}{c}190115^{\mathrm{a}} \\
{[3401]}\end{array}$ & $\begin{array}{c}153617^{\mathrm{a}} \\
{[6331]}\end{array}$ & $\begin{array}{c}145917^{\mathrm{a}} \\
{[8918]}\end{array}$ & $\begin{array}{l}141480^{\mathrm{a}} \\
{[14350]}\end{array}$ & $33.00^{\mathrm{a}}$ \\
\hline
\end{tabular}

*NUE was evaluated in terms of 'Partial Factor Productivity' of Applied Nutrient (PFP $\left.{ }_{N P K}\right)$

Note: The means marked with different letters in the same column were significantly different at $P<0.05$ under Duncan's New Multiple Range Test.

Year wise comparison indicated an interesting pattern of crop yield under the studied farming systems (Figure 5). Under CCM, yield did not follow any consistent pattern during the two years study period. During $2^{\text {nd }}$ year slightly lower yield was obtained under variety 'Jyoti', while just the opposite trend was recorded under varieties Chandramukhi and Super 6. In case of green farming however, yield increased in the $2^{\text {nd }}$ year as compared to $1^{\text {st }}$ year's performance; irrespective of experimental site and potato variety. During $2^{\text {nd }}$ year while slightly lower (-1.79 percent) yield (on an average) was recorded under CCM, the same increased by about 7.16 percent, in case of green farming plots. 


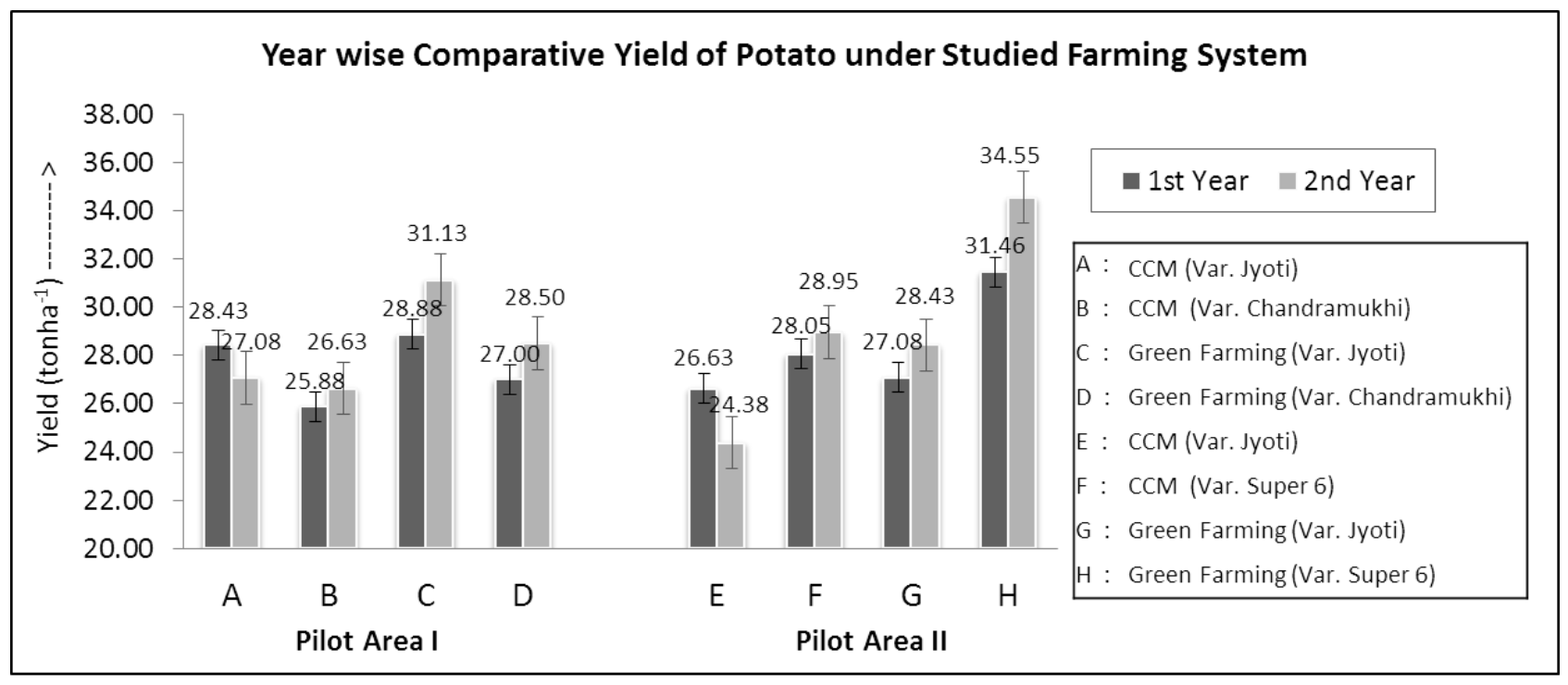

Figure 5: Comparative yield performance of potato under CCM and green farming

In case of green farming adoption of organic plant management (utilizing IRF) at different stages of plant growth; perhaps activated the plant metabolic functions leading to better nutrient uptake, assimilation, translocation and storage; finally culminating in higher tuber yield. Similar improvement in plant functioning under organic (IRF) plant management was documented in various other crops viz. tomato, black gram, green gram (Sengupta et al., 2011; Bera et al., 2014b; Barik et al., 2014b;) okra, cabbage (Barik et al., 2014a; 2014c) and rain-fed/ winter paddy (Mukhopadhyay et al., 2015).

\subsection{Soil quality development}

Variation in soil properties was studied before initiation of experiment and after harvest of potato tubers (Table 6). Analysis revealed that soil of all the experimental plots were slightly acidic in reaction, $\mathrm{pH}$ varying from 6.46 to 6.49. Electrical conductivity (EC), which reflects soil fertility (except in salt effected problematic soil) was found to increase in case of compost treated plots indicating steady nutrient mineralization. Increasing trend of organic carbon was noticed in green farming plots, where Novcom compost was applied during land preparation. Potato produces more dry matter than any other food crop and therefore, requires higher amount of nutrient inputs (Kushwah and Singh, 2011).The imbalanced and indiscriminate use of fertilizers in intensive cropping system without adequate restorative practices may pose threat towards sustainability of the system (Jatav et al., 2013). Soil fertility in terms of available - $\mathrm{N}, \mathrm{P}_{2} \mathrm{O}_{5}, \mathrm{~K}_{2} \mathrm{O}$ and $\mathrm{SO}_{4}{ }^{-}$ showed an increasing trend under both the studied farming systems. 
Table 6: Change in soil quality under studied farming systems (as average of both seasons)

\begin{tabular}{|c|c|c|c|c|c|c|c|}
\hline \multirow[b]{2}{*}{ Treatments } & \multicolumn{7}{|c|}{ Soil Physicochemical Properties } \\
\hline & $\begin{array}{c}\text { pH } \\
(1: 2.5)\end{array}$ & $\begin{array}{c}\text { EC } \\
\left(\mathbf{d S m}^{-1)}\right.\end{array}$ & $\begin{array}{l}\text { Org.- C } \\
(\%)\end{array}$ & \multicolumn{4}{|c|}{$<$------------ kgha' ${ }^{-1}$} \\
\hline $\begin{array}{l}\mathrm{T}_{1}: \text { Conventional Crop } \\
\text { Management (CCM) }\end{array}$ & $\begin{array}{l}6.46^{*} \\
(6.31)\end{array}$ & $\begin{array}{c}0.034 \\
(0.035)\end{array}$ & $\begin{array}{l}0.75 \\
(0.74)\end{array}$ & $\begin{array}{c}354.21 \\
\left(394.32^{* *}\right)\end{array}$ & $\begin{array}{c}68.43 \\
\left(73.45^{* *}\right)\end{array}$ & $\begin{array}{c}241.06 \\
\left(245.62^{*}\right)\end{array}$ & $\begin{array}{c}34.53 \\
(35.67)\end{array}$ \\
\hline \multirow[t]{3}{*}{$\begin{array}{l}T_{2}: \text { Green Farming } \\
\text { utilizing IRF }\end{array}$} & $\begin{array}{c}6.49 \\
(6.54)\end{array}$ & $\begin{array}{c}0.031 \\
\left(0.038^{* *}\right)\end{array}$ & $\begin{array}{c}0.74 \\
\left(0.79^{* *}\right)\end{array}$ & $\begin{array}{c}357.69 \\
\left(386.21^{* *}\right)\end{array}$ & $\begin{array}{c}65.21 \\
\left(68.79^{*}\right)\end{array}$ & $\begin{array}{c}237.51 \\
(235.21)\end{array}$ & $\begin{array}{c}36.32 \\
\left(38.84^{*}\right)\end{array}$ \\
\hline & \multicolumn{7}{|c|}{ Soil Biological Properties } \\
\hline & MBC & SR & FDA & qMBC & $\mathrm{qCO}_{2}$ & qFDA & QR \\
\hline $\begin{array}{l}T_{1} \text { : Conventional Crop } \\
\text { Management }(\mathrm{CCM})\end{array}$ & $\begin{array}{c}279.42 \\
(271.31)\end{array}$ & $\begin{array}{c}0.586 \\
\left(0.623^{* *}\right)\end{array}$ & $\begin{array}{c}26.31 \\
(28.42)\end{array}$ & $\begin{array}{l}3.73^{*} \\
(3.67)\end{array}$ & $\begin{array}{l}2.10 \\
\left(2.30^{* *}\right)\end{array}$ & $\begin{array}{c}0.351 \\
\left(0.384^{* *}\right)\end{array}$ & $\begin{array}{c}0.08 \\
(0.09)\end{array}$ \\
\hline $\begin{array}{l}\mathbf{T}_{2}: \text { Green Farming } \\
\text { utilizing IRF }\end{array}$ & $\begin{array}{c}278.16 \\
\left(312.24^{* *}\right)\end{array}$ & $\begin{array}{c}0.584 \\
(0.591)\end{array}$ & $\begin{array}{c}25.21 \\
\left(39.23^{* *}\right)\end{array}$ & $\begin{array}{c}3.76 \\
\left(3.95^{* *}\right)\end{array}$ & $\begin{array}{l}2.10^{* *} \\
(1.89)\end{array}$ & $\begin{array}{c}0.341 \\
\left(0.497^{* *}\right)\end{array}$ & $\begin{array}{c}0.08 \\
(0.08)\end{array}$ \\
\hline
\end{tabular}

Note: MBC-Microbial Biomass Carbon ( $\mu \mathrm{g} \mathrm{CO}_{2}-\mathrm{C} / \mathrm{g}$ dry soil), SR-Soil Respiration, FDA- Fluorescein Di-acetate Hydrolysis ( $\mu \mathrm{g} / \mathrm{g}$ dry soil), qMBC-Microbial Quotient (\%), qCO - Microbial Metabolic Quotient, qFDA: Specific hydrolytic activity (\%),QR-Soil Microbial Respiration quotient.

Figure in parenthesis indicate analytical values of post harvest soil samples taking average of the two seasons.

$T$-test for 2 dependent means (* significant at $P<0.05$ and $* *$ significant at $P<0.01$ ).

Microbial activity is probably the most important factor that controls nutrient re-cycling in soil. Microorganisms participate in disintegration and decomposition processes leading to the release of nutrients trapped in plant, animal debris, rock and minerals; as well as synthesize and release hormones that are essential for plant growth (Gogoi et al., 2003). Anderson (2003) pointed out that the $\mathrm{MBC} / \mathrm{OC}$ ratio and metabolic quotient $\left(\mathrm{qCO}_{2}\right)$ could be used as more sensitive indicators of soil microbial response to land use, soil management, and environmental variables. Microbial biomass carbon was found to increase under green farming, whereas slight reduction in value was noticed under CCM. Increase in soil respiration in green farming plots, might be due to increased microbial activity for utilization of added organic source. This was corroborated by enhanced FDA value, that represents overall enzymatic activity by soil microbes. Microbial quotient (qMBC) i.e., the ratio of $\mathrm{C}_{\mathrm{mic}} / \mathrm{C}_{\mathrm{org}}$, increased in green farming plots indicating increase in microbial activity. $\mathrm{qCO}_{2}$ value was found to increase under $\mathrm{CCM}$. In general, conventional agro-systems present higher values in comparison to organic or natural ecosystems; indicating comparatively more stressed conditions under the former (Dilly \& Munch, 1998). Simultaneously
qFDA (FDA per unit organic carbon) value of soil decreased in CCM plots. Decrease in qFDA under conventional practice, perhaps indicated stress on microbial community, thereby requiring higher energy for maintenance.

\subsubsection{Soil Development Index}

Soil Development Index (SDI) is a concept to quantify the extent of positive changes in different soil quality parameters for expression of overall soil development; to enable easy understanding of the end-users. (Bera et al., 2014a). Soil Development Index was noticeably higher under green farming plots (where Novcom compost was integrated with chemical fertilizer) as compared to CCM plots, receiving only chemical fertilizer (Fig. 6). The variation was especially significant in terms of soil biological properties, which was recordably higher in green farming plots as compared to plots receiving chemical fertilizers. Similar enhancement of soil quality under organic manure application was documented by Golabi et al. (2004), Gulshan et al. (2013), Das et al. (2013) and Bera et al. (2014). 


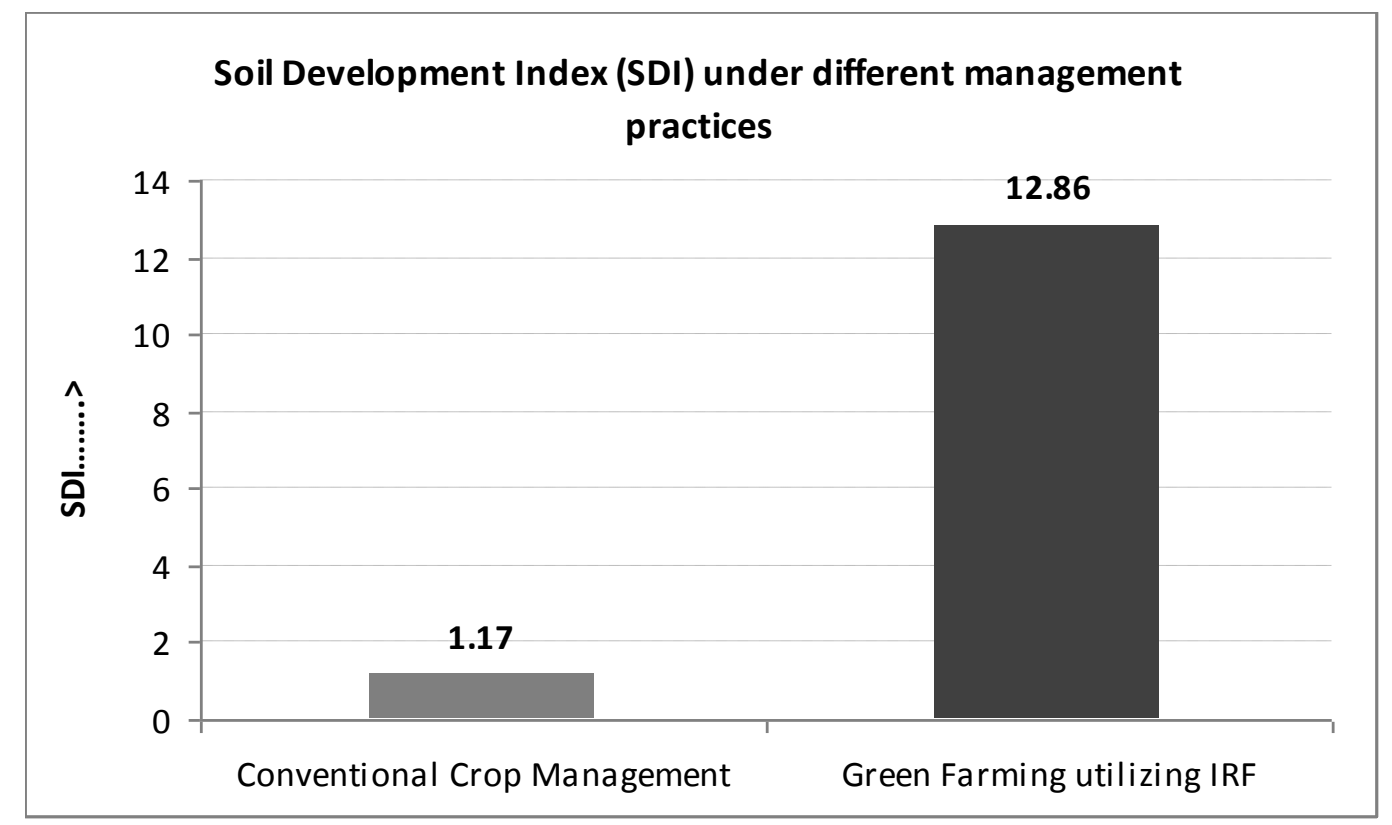

Figure 6: Soil quality development under CCM and green farming

\subsection{Potato quality under studied farming systems}

Analysis of different quality parameters of potato was done to assess qualitative differences in potato (if any) under varying management practice (Table 7). Mean specific gravity of potato was the highest (1.084) under green farming as compared to CCM (1.071). Specific gravity of potato positively correlated with dry matter and starch content, as was also noted by Marwaha (1997), Abbas et al. (2011) and Kaur \& Agarwal (2014); but presented negative correlation with reducing sugar content (Iritani \& Weller, 1974; Salamoni et al.,
2000). Starch, comprising $65-80 \%$ of dry matter content, is considered to be the main constituent of potato (Kadam et al., 1991a). Starch content (mean value $13.73 \mathrm{~g} / 100 \mathrm{~g}$ tissue) was about 15.6 percent higher in case of potato grown under green farming as compared to those produced under CCM. Since starch comprises the largest part of dry matter, it has direct influence on technological quality, especially with regard to the texture of the processed products (Kadam et al., 1991b).

Table 7: Quality of potato grown under studied farming systems

\begin{tabular}{lcc}
\hline Quality parameter & $\begin{array}{c}\text { Conventional Crop } \\
\text { Management }(\mathbf{C C M})\end{array}$ & Green Farming utilizing IRF \\
\hline Specific gravity & $1.045-1.112$ & $1.049-1.124$ \\
& $(1.071 \pm 0.012)$ & $1.084^{* *} \pm 0.011$ \\
Starch (g/ 100g tissue) & $6.81-19.91$ & $7.66-22.56$ \\
& $(11.87 \pm 2.034)$ & $\left(13.73^{* *} \pm 2.061\right)$ \\
$\mathrm{pH}$ & $5.99-6.10$ & $6.11-6.38$ \\
& $(6.02 \pm 0.016)$ & $\left(6.17^{* *} \pm 0.019\right)$ \\
Titratable acidity (\%) & $0.30-1.02$ & $0.16-0.27$ \\
& $\left(0.51^{* *} \pm 0.115\right)$ & $(0.23 \pm 0.019)$ \\
Vitamin C (mg/ 100 mg tissue) & $10.80-12.00$ & $12.00-14.40$ \\
& $(11.40 \pm 0.364)$ & $\left(13.20^{* *} \pm 0.318\right)$
\end{tabular}

Figure in parenthesis indicate mean value and standard error, $\mathrm{T}-$ test for 2 independent means (* significant at $\mathrm{P}<0.05$ and $* *$ significant at $\mathrm{P}<0.01)$. 
Factors that may interfere in a negative and/ or indirect way on the technological quality of tubers are pulp $\mathrm{pH}$ and total titratable acidity. The $\mathrm{pH}$ index determines deterioration potential by fermentation and the activity of enzymes (Cecchi, 1999).The phosphorylase enzyme acts predominantly on starch breakdown (Jadhav et al., 1991), with maximum activity at pH 5.5 (Iritani \& Weller, 1973). In addition, pulp $\mathrm{pH}$ is variable and presents a negative correlation (-0.86) with reducing sugars accumulation (Iritani \& Weller, 1973). Total acidity on the other hand quantifies organic acids present in foods and, in general, there is a tendency of reduction in their contents because of respiration and/or due to conversion into sugars (Chitarra \& Chitarra, 1990), which could contribute toward browning of the fried product. Lower $\mathrm{pH}$ (6.02) value and higher titratable acidity ( 0.51 percent) in case of conventionally grown potato (as against those grown under green farming) indicated its inferior quality in terms of faster degradability and higher browning potential, when fried.

Potatoes are a steady reliable source of vitamin C (ascorbic acid) in human diet (FAO 2008). Although vitamin $\mathrm{C}$ is sensitive to heat, and breaks down to some degree on cooking, enough is still retained to make cooked potatoes a rich source of this nutrient. Vitamin C works as antioxidant which helps protect cells from free radical damage apart from its requirement for healthy skin, teeth, gums, muscles and bones. It also helps with the absorption of iron from plant foods, which is poorly available to the body otherwise. Vitamin C $(13.20 \mathrm{mg} /$ $100 \mathrm{mg}$ tissue) was about 15.7 percent higher in potatoes grown under green farming as compared to their conventional counterparts, which corroborated the findings of Hamouz et al. (1999), Hamouz et al. (2005) and Zarzyńska (2013). As per their observation ascorbic acid content in potato tubers was influenced by the method of cultivation; with higher levels in potatoes cultivated following ecological pathway i.e., without using any chemical protection as compared to those produced under conventional methods. According to Widmann et al. (2008) fertilizers used to increase potato growth represent an ecological risk because they penetrate potato's tissues, affect their metabolism and change the chemical composition of the tubers, reducing the content of their active principles. Therefore, potato grown under organic environment, tend to be qualitatively superior in comparison to its conventional counterpart.

\subsection{Comparative energy use efficiency under studied farming systems}

Conventional agriculture's energy inefficiency is directly tied to the high energy consumption of producing and transporting synthetic pesticides and fertilizers used to grow these crops. Whereas organic agriculture utilizes manure, legumes, and other natural sources of nitrogen, which replace the fossil fuels used for manufacturing synthetic nitrogen fertilizer; with natural biological process (Ziesemer, 2007).

Total energy input in the form of direct, indirect, renewable and non-renewable; are presented in Table 9. In case of green farming about $49 \%$ of total energy input was in the form of direct energy, as compared to only $22 \%$ in case of CCM plots.

Energy productivity or the potato output per unit energy application (Fig. 7) was more under green farming (1.26 $\left.\mathrm{kg} \mathrm{MJ}^{-1}\right)$ as compared to $\mathrm{CCM}\left(0.56 \mathrm{~kg} \mathrm{MJ}^{-1}\right)$. This can be attributed to the differences in the level of technology and other characteristics of each treatment (Zangeneh et al., 2010). Specific energy was 55.6 percent less under green farming vs. CCM; indicating higher sustainability under the former. The result was well corroborated with $34410.09 \mathrm{MJ} \mathrm{ha}^{-1}$ excess gain in net energy under green farming as compared to CCM. Energy intensiveness was computed as energy consumed in crop production per unit market value of crop produced (Lockeretz et al., 1977). Lower energy intensiveness under green farming $\left(0.09 \mathrm{MJRs}^{-1} v s .0 .21\right.$ $\mathrm{MJRs}^{-1}$ under CCM) indicated towards the sustainable agriculture practice. 

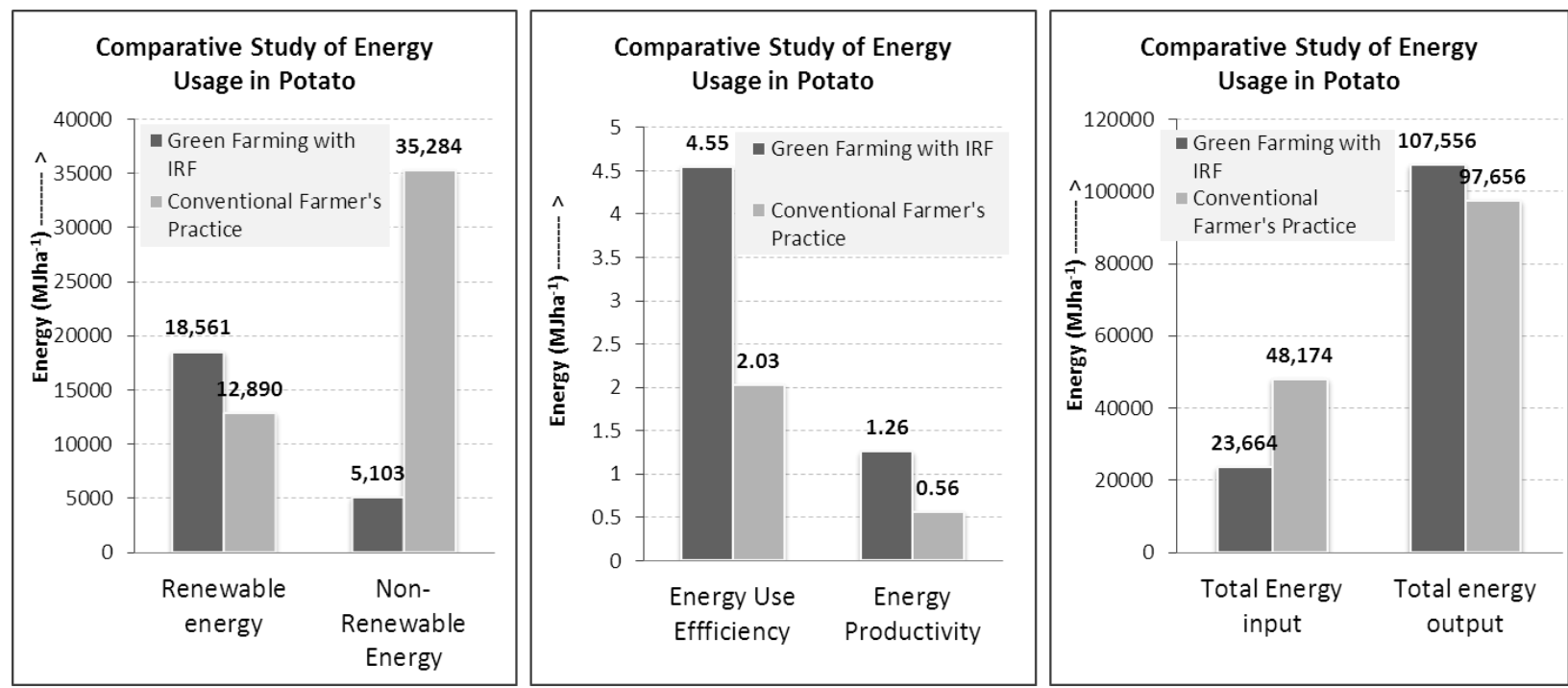

Figure 7: Comparative energy usage for potato cultivation under green farming and conventional crop management

\subsection{Economics of potato cultivation under studied farming systems}

Total cost of potato cultivation (Table 8) was found to be almost the same (Rs. 1,57,012 under green farming and Rs. 1,57,462 under CCM) under both the farming systems.
Net income under green farming was 30.98 percent higher as compared to CCM due to better tuber yields under the former. Green farming also led to higher economic gains as compared to CCM in terms of other financial components like net return, return per rupees invested and benefit cost ratio. The findings pointed towards the scope for financial security under this crop production system.

Table 8: Economics of potato cultivation under studied farming systems

\begin{tabular}{lc|c}
\hline Economics & $\begin{array}{c}\mathbf{T}_{\mathbf{1}} \text { : Conventional Crop } \\
\text { Management }(\mathbf{C C M})\end{array}$ & $\begin{array}{c}\mathbf{T}_{\mathbf{2}} \text { : Green Farming utilizing } \\
\text { IRF }\end{array}$ \\
\hline Total cost (Rs./ha) & 157462 & 157012 \\
Gross income (Rs./ha) & 229125 & 250875 \\
Net income (Rs./ha) & 71663 & 93863 \\
Returns per rupees invested & 0.49 & 0.60 \\
Benefit cost ratio & 1.49 & 1.60 \\
\hline
\end{tabular}

Note: 100 Indian Rupee $=1.487$ US\$ or 1.325€ or 1.050 British $£$ (as on 2016 June 14).

\section{CONCLUSION}

Green farming practice utilizing IRF Technology delivered positive results encompassing all the critical aspects of crop (in this case potato) cultivation i.e., yield, quality, energy investments and soil health; besides ensuring economic sustenance. Higher tuber yield and rapid bulking of potato tubers under green farming indicated the positive influence of organic plant management (utilizing IRF) towards efficient photosynthesis, translocation and synthesis of large molecular weight substances within storage organs; or in other words better plant metabolic functioning. The finding was corroborated by the better technological quality of potato tubers under green farming versus conventional crop management. The criteria of economic sustenance under changing climatic pattern was also better ensured under this farming, which showed higher withstanding capacity against production loss or fall in market price; as compared to conventional 
crop management. The study also revealed that complete cessation of chemical pesticides and other agrochemicals was possible even for an input intensive crop like potato, by undertaking initiatives towards activation of plant biochemical functions. Energy efficiency is an integral part of sustainable agriculture.
As compared to conventional farming, green farming ensured higher use of renewable energy and significantly lower energy intensiveness for potato cultivation; thereby presenting the prototype for sustainable agriculture.

\section{REFERENCES}

Abbas, G., Farooq, K., Hafiz, I.A., Hussain, A., Abbasi, N.A., Shabbir, G. (2011). Assessment of processing and nutritional quality of potato genotypes in Pakistan. Pakistan Journal Agricultural Sciences, 48(3), 169-175.

Anderson, T.H. (2003). Microbial eco-physiological indicators to assess soil quality. Agriculture, Ecosystems and Environment, 98, 285-293. doi:10.1016/S0167-8809(03)00088-4

Banaeian, N., Omid, M., Ahmadi, H. (2011). Energy and economic analysis of greenhouse strawberry production in Tehran province of Iran. Energy Conversion and Management, 52(2), 1020-1025. doi:10.1016/j.enconman.2010.08.030

Barik, A.K., Chatterjee, A.K., Datta, A., Saha, S., Bera, R., Seal, A. (2014b). Evaluation of Inhana Rational Farming (IRF) Technology as an Effective Organic Option for Large Scale Paddy Cultivation in Farmer's Field - A Case Study from Kowgachi-II Gram Panchayat, North 24 Parganas, West Bengal. The International Journal of Science \&Technology, 2 (5), 183-197.

Barik, A.K., Chatterjee, A.K., Datta, A., Bera, R., Seal, A. (2014c). Evaluation of Inhana Rational Farming (IRF) Technology as an effective organic package of practice- a case study of state horticultural research \& development station, Krishnanagar, Nadia, West Bengal. Centra European Journal of Experimental Biology, 3(3), 1-15.

Barik, A.K., Chatterjee, A.K., Mondal, B., Datta, A., Saha, S., Nath, R., Bera, R., Seal, A. (2014a). Adoption of Rational Farming Technology for Development of a Model for Exploring Sustainable Farming Practice in Farmer's Field. The International Journal of Science \& Technology, 2(4), 147-155.

Bera, R., Datta, A., Bose, S., Dolui, A.K., Chatterjee, A.K., Dey, G.C., Barik, A.K., Seal, A. (2013b). Comparative Evaluation of Compost Quality, Process Convenience and Cost under Different Composting Method to assess their Large Scale Adoptability Potential as also Complemented by Compost Quality Index. International Journal of
Scientific and Research Publications, 3(6), 406417.

Bera, R., Khan, M., Mazumdar, D. (2013a). Soil Development Index (SDI) to evaluate effectivity of different organic inputs towards soil quality development under FAO-CFC-TBI Project at Maud T. E., Assam. Oral presentation G36 at: 100th Indian Science Congress; 2013 Jan 3-7; Kolkata, p. 272 .

Bera, R., Seal, A., Datta, A., Saha, S., Dolui, A.K., Khan, M., Mazumdar, D. (2014a). Formulation of a Soil Development Index (SDI) to Evaluate the Effectivity of Organic Soil Management under FAO-CFC-TBI Project at Maud Tea Estate, Assam, India.

International Journal of Advance Agricultural Research, 2(12), 318-329.

Bera, R., Seal, A., Datta, A., Sengupta, K. (2014b). Evaluation of Inhana Rational Farming Technology as an Organic Package of Practice for Effective and Economic Vegetable Cultivation in Farmers' Field. Journal of Natural Product and Plant Resources, $4(3), 82-91$.

Bhatia, A.K., Pandita, M.L., Khurana, S.C. (1992). Plant growth substances and sprouting conditions. 1. Effect on haulm growth of plant raised from nursery rooted sprouts. Journal of the Indian Potato Association, 19, 21-24.

Biswas, R.K., Majumder, D., Sinha, A. (2011). Impacts and Constraints Evaluation of Organic Farming in West Bengal. Study No. - 167. Visva - Bharati, Santiniketan, India: Agro-Economic Research Centre. Retrieved from: http://www.visvabharati.ac.in/InstitutionsCentresSchools/Contents/A ERC-DETAIL/Summary-167.pdf

Black, C.A. (1965). Method of soil analysis, Part-1. Madison, USA: Am. Soc. Agron. Inc.

Cassman, K.G., Gines, G.C., Dizon, M.A., Simon, M.I., Alcatara, J.M. (1996). Nitrogen use efficiency in tropical lowland rice systems: contributions from indigenous and applied nitrogen. Field Crops Research, 47(1), 1-12. doi:10.1016/03784290(95)00101-8 
Cecchi, H.M. (1999). Theoretical and practical fundamentals in food analysis (p. 211-212). Campinas: Unicamp Publishing House.

Chatterjee, A.K., Barik, A. K., De, G.C., Dolui, A.K., .Seal, A. (2014). Adoption of Inhana Rational Farming (IRF) Technology as an Organic Package of Practice towards Improvement of Nutrient Use Efficiency of Camellia sinensis through Energization of Plant Physiological Functioning. The International Journal of Science \& Technology, 2(6), 377-395.

Chaboussou, F. (2004). Healthy crops: A new agricultural revolution (p. 244). Oxford, England: Jon Carpenter Publishing.

Chitarra, M.I.F., Chitarra, A.B. (1990). Pós-colheita de frutos e hortaliças:fisiologia e manuseio. [Post harvest of Fruits and Vegetables:Physiology and Handling] (p. 320). Lavras: FAEPE.

Dias, M.C. (2012). Phytotoxicity: An Overview of the Physiological Responses of Plants Exposed to Fungicides. Journal of Botany, 2012, 1-4. doi:10.1155/2012/135479

Dilly O, Munch JC. (1998). Ratios between estimates of microbial biomass content and microbial activity in soils. Biology and Fertility of Soils, 27, 374-379. doi: $10.1007 / \mathrm{s} 003740050446$

Epstein, E. (1997). The science of composting (p. 383 415). Lancaster, PA: Technomic Publishing .

Evanylo, G. (2006). Compost Maturity and Indicators of Quality: Laboratory Analyses and On-Farm Tests. Retrieved from: http://www.mawaterquality.org /industry_change / compost_school / Compost \% 20 quality_Evanylo.pdf

Feltran, J.S., Lemos, L.B., Vieites, R.L. (2004). Technological quality and utilization of potato tubers. Scientia Agricola (Piracicaba, Braz.), 61(6), 598-603. doi:10.1590/S0103-90162004000600006

FAI [Fertilizer Association of India]. (2007). The Fertilizer (control) Order 1985. New Delhi, India: FAI.

FAO [Food and Agriculture Organisation]. (2008). Potatoes, nutrition and diet. Fact sheet. International Year of the Potato 2008. Retrieved from: http://www.fao.org/potato2008/en/potato/IYP-6en.pdf

Garg, V.N. (2014). Training Workshop of Potato farmers of UP at Kannauj by Experts from Netherlands ; October 27, 2014; India. Retrieved from: http://vngarg.blogspot.in/2014/10/trainingworkshop-of-potato-farmers-of.html
Ghorbani, R., Mondani, F., Amirmoradi, S., Feizi, H., Khorramdel, S., Teimouri, M., Sanjani, S., Aghel H. (2011). A case study of energy use and economical analysis of irrigated and dryland wheat production systems. Applied Energy, 88, 283-288. doi:10.1016/j.apenergy.2010.04.028

Gogoi, S., Bhuyan, M.K., Karmakar, R.M. (2003). Dynamics of microbial population in tea ecosystem. Journal of the Indian Society of Soil Science, 51 (3), 252-257.

Golabi, M.H., Denney, M.J., Iyekar, C. (2004). Use of composted organic wastes as alternative to synthetic fertilizers for enhancing crop productivity and agricultural sustainability on the Tropical Island of Guam. In: Conserving Soil and Water for Society: Sharing Solutions. Paper No. 234. Proceedings of 13th International Soil Conservation Organisation Conference ; 2004 July 4-8; Brisbane, p.1-6.

Gomez, K.A., Gomez, A.A . (1984). Statistical Procedures for Agricultural Research (p. 684). New York: John Wiley and sons.

Gulshan, A.B., Saeed, H.M., Javid, S., Meryem, T., Atta, M.I., Amin-ud-Din, M. (2013). Effects of animal manure on the growth and development of okra (Abelmoschusesculentus L.). ARPN Journal of Agricultural and Biological Science, 8(3), 213-218.

Hamouz, K., Lachman, J., Doak, P., Pivec, V. (2005).The effect of ecological growing on the potatoes yield and quality. Plant, Soil and Environment, 51 (9), 397-402.

Hamouz, K., Lachman, J., Vokal, B., Pivec, V. (1999). Influence of environmental conditions and way of cultivation on the polyphenol and ascorbic acid content in potato tubers. Rostlinna Vyroba, 45(7), 293-298.

Harwood, J., Heifner, R., Coble, K., Perry, J., Somwaru, A. (1999). Managing Risk in Farming: Concepts, Research, and Analysis. Agricultural Economic Report No. 774. US: Market and Trade Economics Division and Resource Economics Division, Economic Research Service, Department of Agriculture, p.1-70.

Iritani, W.M., Weller, L.D. (1973).The development of translucent end tubers. The American Journal of Potato Research, 50, 223-233. doi:10.1007/BF02849356

Iritani, W.M., Weller, L.D. (1974). Some factors influencing the $\mathrm{pH}$ of apical and basal portions of Russet Burbank and Norgold potatoes. The American Journal of Potato Research, 51, 119-125. doi:10.1007/BF02851344 
Jackson, M.L. (1973). Soil Chemical Analysis. New Delhi: Prentice Hall of India Pvt. Ltd.

Jadhav, S.J., Mazza, G., Desai, U.T. (1991). Postharvest handling and storage. In: D.K. Salunkhe, S.S. Kadam, S.J. Jadhav. (Eds.) Potato production, processing and products (p.69-109). Boca Raton: CRC Press.

Jatav, M.K., Dua, V.K., Kumar, M., Trehan, S.P., Kumar, S. (2013). Spatial distribution of soil available Nutrients in the potato growing pockets of Hoshiarpur district of Punjab. Potato Journal, 40 (2), 128-134.

Kadam, S.S., Dhumal, S.S., Jambhale, N.D. (1991a). Structure, nutritional composition, and quality. In: D.K. Salunkhe, S.S. Kadam, S.J. Jadhav. (Eds.) Potato production, processing and products (p.935). Boca Raton: CRC Press.

Kadam, S.S., Wankier, B.N., Adsule, N.R. (1991b). Processing. In: D.K. Salunkhe, S.S. Kadam, S.J. Jadhav. (Eds.) Potato production, processing and products (p.111-154). Boca Raton: CRC Press.

Karim, A.A., Ramasamy, C. (2000). Expanding Frontiers of Agriculture: contemporary issues. Ludhiana, India: Kalyani Publishers.

Kaur, S.,Aggarwal, P. (2014). Studies on Indian Potato Genotypes for their Processing and Nutritional Quality Attributes. International Journal of Current Microbiology and Applied Sciences, 3(8), 172-177.

Khan, M.A., Hossain, S.M.A. (2007). Study on Energy Input, Output and Energy Use Efficiency of Major Jute Based Cropping Pattern. Bangladesh Journal of Scientific and Industrial Research, 42(2), 195202. doi:10.3329/bjsir.v42i2.472

Kumar, M., Baishya, L.K., Ghosh, D.C., Gupta, V.K. (2011). Yield and quality of potato (Solanum tuberosum ) tubers as influenced by nutrients sources under rained conditions of Meghalaya. Indian Journal of Agronomy, 56(3), 260-66.

Kumar, M., Jatav, M.K., Trehan, S.P. (2008).Contributing of organic sources to potato nutrition at varying nitrogen levels. In: Proceedings of Global Potato Conference; 2008 Dec 9-12. New Delhi: Indian Potato Association.

Kushwah, V.S., Singh, S.P. (2011). Relative performance of low input and high input technology for potato production in India. Potato Journal, 38(1), 56-60.

Lockeretz, W., Klepper, R., Commoner, B., Gertler, M, Fast, S, O'leary, D., Blobaum, R. (1977). Economic and energy comparison of crop production on organic and conventional corn belt farms. In W. Lockeretz (Eds.) Agriculture and Energy (p. 94). NY: Academic Press.

Marwaha, R.S. (1997). Processing of potatoes: Current status, need, future potential and suitability of Indian varieties: A critical appraisal. Journal of Food Science and Technology, 3, 457-471.

Mohapatra, B.K., Maiti, S., Satapathy, M.R. (2008). Integrated nutrient management in potato (Solanum tuberosum )-Jute (Corchorus olitorius) sequence. Indian Journal of Agronomy, 53 (3), 205-09.

Mollah, M.R.A., Islam, N., Sarkar, M.A.R. (2011). Integrated nutrient management for potato mungbean-T.aman rice cropping pattern under level Barind agroecological zone. Bangladesh Journal of Scientific and Industrial Research, 36(4), 711-722.

Mondal, S.S., Acharya, D., Ghosh, A., Bug, A. (2005). Integrated nutrient management on the Growth, productivity and quality of Potato in indo-gangetic plains of West Bengal. Potato Journal, 32 (1 - 2), 75-78.

Mukhopadhyay, K., Mukherjee, S., Seal, A., Bera, R., Dolui, A.K., Rahman, F.H. (2015). Evaluation of new technology with fully organic inputs toward production of paddy with special reference to soil quality development- A case study of Howrah Krishi Vigyan Kendra. Article 65. In: Souvenir of National Seminar on Soil Health Management and food Security: Role of Soil Science Research and Education; 2015 Oct 8-10; Kolkata, India, p. 101102.

Nambiar, K.K.M. (1998). Integrated use of organic manures and chemical fertilizers in red soils for sustainable agriculture. In J. Sehgal, W.E. Blum, K.S. Gajbhiye (Eds. ) Red and Lateritic Soils; Vol1, Managing red and lateritic soils for sustainable agriculture (p.367-376). Netherlands: Balkema Publishers.

Ojha, M.D., Saha, B. (2014). Organic Potato in Nalanda (Bihar): Using Eco-Friendly Agri. Bios Inputs. Indian Research Journal of Extension Education, 14 (3), $119-121$.

Pandey, N.K. (2013). Economics of seed potato production in India. Summer School on Advances in Quality Potato Production and Post-harvest Management (2013 July 16 -Aug 5). Shimla, India: Central Potato Research Institute. Retrieved from: http://14.139.61.86/E-Book-SummerSchool/.html

Peer, Q.J.A., Ahmad, N., Kaur, J., Chesti, M.H., Ahmad, H.S., Bhat, A., Bhat, B.A. (2013). Study on economics of potato growing towards livelihood security. African Journal of Agricultural Research, 8(45), 5639-5644. 
Raj, D., Joshi, V.K., Lal, B.B. (2011).Yield, quality and storability of the potato flour of different Indian cultivars. International Journal of Food and Fermentation Technology, 1(1), 111-117.

Sadasivam, S., Manickam, A. (2011). Biochemical Methods (3rd edn.); Reprinted. New Delhi: New Age International (p) limited.

Salamoni, A.I., Pereira, A da S., Viégas, J., Campos, A.D., Chalá, C.S. de A. (2000). Genetic variance of reducing sugars and dry matter and their correlations with agronomic traits in potatoes. Agricultural Research Brazilian, 35, 1441-1445.

Seal, A., Bera, R., Chatterjee, A.K., Dolui, A.K. (2012). Evaluation of a new composting method in terms of its biodegradation pathway and assessment of compost quality, maturity and stability. Archives of Agronomy and Soil Science, 58(9), 995-1012. doi:10.1080/03650340.2011.565410

Seal, A., Bera, R., Mukhopadhyay, K., Mukherjee, S. (2015). Recycling of poultry litter through Novcom composting method: A case study from Howrah KrishiVigyan Kendra, West Bengal, India. Journal of Pharmaceutical and Scientific Innovation, 4(3), 176-179. doi:10.7897/2277-4572.04339

Sen, H.S. (2011). Agriculture and Horticulture in West Bengal: Present Status Holds Promise while its Future Demands Long Term Planning with Focus on Commercialization. Presented at: Orientation Program for IAS Probationers 2010 batch at ATI; 2011 June 20; Kolkata, India. Retrieved from: http://hssen-hssen-

coastalmanagement.blogspot.in/2011/06/agriculture -in-west-bengal.html

Sengupta, K., Bhui, S., Mondal, M. (2011). NovcomAn Effective compost for blackgram production. Extended summary: International Symposium on System intensification towards Food and Environmental Security; 2011 Feb 24-27; Kalyani, India BCKV, p. 94.

Sharma, R.C., V. Sunaina, N.C. Upadhyay., M. Kumar. (1996). Effect of green manuring, organics and biofertilizer on tuber production in potato on a typicUstochrept. In: Proceeding of the XIV National Symposium on Agronomy, Environment and Food Security for 21st century, CCSHAU, Hisar, India. 10-14 Dec 1996, p. 183-84.

Singh, J.P. (1999). Potassium fertilization of potatoes in north India. In: Proceeding of IPI workshop on "essential role of potassium in diverse cropping system", held at the 16th world congress of soil science, Montpellier, France 20-26 August,1998. Basel, Switzerland: International Potash Institute, p. 123-27

Trautmann, N.M., Krasny, M.E. (1997). The science of composting. In: Composting in the classroom (p. 15). Ithaca, NY: Cornell University.

Venkatasalam, E.P., Singh, S., Sharma, S. (2012). Effect of organic manures on yield and yield attributing characters of potato. Potato Journal, 39 (1), 84-87.

Wheeler, B.E.J. (1969). An Introduction to Plant Diseases (p.301). London: John Wiley and Sons Ltd.

Widmann, N., Goian, M., Ianculov, I., Dumbravă, D., Moldovan, C. (2008). Method to Starch Content determination from plants by Specific Weight. Scientific Papers, Animal Science and Biotechnologies, 41 (1), 814-818.

Yadav, R.L. (2003). Assessing on-farm efficiency and economics of fertilizer $\mathrm{N}, \mathrm{P}$ and $\mathrm{K}$ in rice wheat systems of India. Field Crops Research, 18, 39-51. doi:10.1016/S0378-4290(02)00198-3

Zahedi M, Eshghizadeh H R, Mondani F. 2014. Energy Use Efficiency and Economical Analysis in Cotton Production System in an Arid Region: A Case Study for Isfahan Province, Iran. International Journal of Energy Economics and Policy, 4(1), 4352.

Zangeneh, M., Omid, M., Akram, A. (2010). A comparative study on energy use and cost analysis of potato production under different farming technologies in Hamadan province of Iran. Energy, 35(7), 2927-33. doi:10.1016/j.energy.2010.03.024

Zarzyńska, K. (2013). Chemical Composition of Potato Tubers in Relation to Crop Production System and Environmental Conditions. Journal of Agricultural Science and Technology B, 3, 689-695.

Ziesemer, J. (2007). Energy use in organic food systems. Report of Natural Resources Management and Environment Department Food and Agriculture Organization of the United Nations. August 2007, Rome. Retrieved from: http://www.fao.org/docs/eims/upload/233069/energ y-use-oa.pdf 